\title{
PEMENUHAN STANDAR SARANA DAN PRASARANA BIMBINGAN DAN KONSELING (Survei Terhadap Sekolah Menengah Atas Negeri di Jakarta Barat)
}

\author{
Fatin Intishar ${ }^{1}$ \\ Dra. Indira Chanum, M.Psi. ${ }^{2}$ \\ Dr. Aip Badrujaman, M.Pd. ${ }^{3}$
}

\begin{abstract}
Abstrak
Penelitian ini bertujuan untuk mengetahui gambaran pemenuhan standar sarana dan prasarana bimbingan dan konseling di sekolah menengah atas negeri Jakarta Barat. Metode yang digunakan adalah survei dengan menggunakan instrument pedoman observasi standar sarana dan prasarana bimbingan dan konseling yang dikembangkan dari pedoman penyelenggaraan bimbingan dan konseling pada pendidikan dasar dan menengah. Sampel yang digunakan dalam penelitian ini sebanyak empat belas sekolah yang ditentukan melalui teknik sampling jenuh.Teknik analisis data yang digunakan untuk mendeskripsikan pemenuhan standar sarana dan prasarana yaitu statistik deskriptif dengan teknin persentase. Hasil penelitian menunjukkan bahwa tiga belas sekolah berada pada kategori tidak memenuhi standar(92,8\%) dan satu sekolah berada pada kategori memenuhi standar (7,14\%). Pada aspek ruang bimbingan dan konseling seluruh sekolah tidak memenuhi standar(100\%) . Pada aspek instrumen pengumpul data tiga belas sekolah berada pada kategori memenuhi standar(92,8\%) dan satu sekolah tidak memenuhi standar(7,14\%). Pada aspek kelengkapan penunjang teknis sepuluh sekolah memenuhi standar(71,4\%) dan empat sekolah lainnya tidak memenuhi standar (28,6\%). Pada aspek dokumen seluruh sekolah memenuhi standar(100\%).Oleh karena itu, aspek sarana dan prasarana bimbingan dan konseling harus mendapatkan perhatian lebih dari berbagai pihak, (Dinas Pendidikan DKI Jakarta, ABKIN, MGBK, Kepala Sekolah, dan Guru BK).
\end{abstract}

Kata Kunci : sarana dan prasarana, bimbingan dan konseling, sekolah.

\section{Pendahuluan}

Penyelenggaraan layanan bimbingan Penyelenggaraan program bimbingan dan konseling yang dilaksanakan di sekolah terwujud ke dalam beberapa layanan yaitu, layanan dasar bimbingan, layanan responsif, layanan perencanaan individual dan du- kungan sistem. Proses penyelenggaraan pendidikan, yang termasuk di dalamnya program bimbingan dan konseling, tidak akan pernah bisa dipisahkan dari aspek dukungan sistem. Dukungan sistem merupakan komponen layanan dan kegiatan manajemen yang secara tidak langsung memberikan bantu-

\footnotetext{
Mahasiswa Jurusan Bimbingan dan Konseling FIP UNJ, fatinintishar84@gmail.com

Dosen Bimbingan dan Konseling FIP UNJ, indirasunito@yahoo.com

3 Dosen Bimbingan dan Konseling FIP UNJ, aip_bj@yahoo.com
} 
an kepada peserta didik, atau memfasilitasi kelancaran perkembangan peserta didik(Syamsu dan Juntika, 2010:29). Salah satu bagian terpenting dari dukungan system adalah sarana dan prasarana.Sarana dan prasarana bimbingan dan konseling harus mampu menciptakan kenyamanan bagi peserta didik dan guru bimbingan dan konseling dan mampu menunjang keterlaksanaan layanan bimbingan dan konseling.

Peraturan Menteri Pendidikan dan Kebudayaan tahun 2014 nomor. 111 pasal 6 ayat 4 dan 5 dikemukakan bahwa layanan bimbinga dan konseling diselenggarakan dalam dua jam per minggu dan tidak hanya fokus pada kegiatan di dalam kelas tetapi juga bias dilakukan di luar kelas. Kondisi ini membuat sarana dan prasarana yang digunakan dalam penyelenggaraan layanan bimbingan dan konseling harus lebih diperhatikan dan dipenuhi agar mampu menunjang keterlaksanaan layanan bimbingan dan konseling. Kegiatan layanan bimbingan dan konseling di sekolah akan berjalan dengan lancar sesuai dengan yang direncanakan, apabila di dukung oleh fasilitas bimbingan dan konseling yang memadai(Sukardi, 2008:97). Sarana dan prasarana bimbingan dan konseling akan mempengaruhi keberhasilan layanan bimbingan dan konseling(Depdiknas, 2008:238).

Penelitian yang dilakukan di SMP Dorowati menghasilkan bahwa $74 \%$ peserta didik di SMP Dorowati Surabaya tidak ingin melakukan konseling dikarenakan ruang bimbingan dan konseling mereka tidak memiliki ruangan khusus sehingga tidak terjamin kerahasiaannya(Sulis, 2013:1). Hasil studi pendahuluan yang dilakukan peneliti di dua sekolah di Jakarta Barat yaitu SMA 84 dan SMA 56 menghasilkan bahwa banyak hambatan yang dialami oleh guru bimbingan dan konseling dikarenakan sarana dan prasarana yang tidak memdai. Beberapa program seperti layanan bimbingan kelompok, konseling kelompok dan konseling individual tidak terlaksana dengan baik dikarenakan sarana dan prasarana yang kurang memadai.Oleh karena itu sarana dan prasarana menjadi isu yang menarik bagi peneliti untuk mengetahui lebih lanjut kondisi sarana dan prasarana yang ada di sekolah dalam lingkup yang lebih besar, yaitu seluruh sekolah menengah negeri atas di Jakarta Barat.

\section{Kajian Teori}

\section{Penyelenggaraan bimbingan dan konseling}

Bimbingan adalah proses pemberian bantuan yang dilakukan oleh orang yang ahli kepada seorang atau beberapa orang individu, baik anak-anak, remaja, maupun dewasa; agar orang yang dibimbing dapat mengembangkan kemampuan dirinya sendiri dan mandiri; dengan memanfaatkan kekuatan individu dan sarana yang ada dan dapat dikembangkan; berdasarkan norma-norma yang berlaku(Zekri, 2012:11) sedangkan ASCA (American School Counselor Association) mengemukakan bahwa: konseling adalah hubungan tatap muka yang bersifat rahasia, penuh dengan sikap penerimaan dan pemberian kesempatan dari konselor kepada konseli, konselor mempergunakan pengetahuan dan keterampilannya untuk membantu konselinya mengatasi masalah-masalahnya (Prayitno, 1994:114). Layanan bimbingan dan konseling terdiri dari layanan dasar bimbingan, layanan responsif, layanan perencanaan individual dan dukungan system.

\section{Sarana dan Prasarana Pendidikan}

Sarana pendidikan adalah peralatan dan pelengkapan yang secara langsung dipergunakan dan menunjang proses pendidikan, khususnya proses belajar mengajar, seperti meja kursi, alat-alat, dan media pengajaran(Mulyasa, 2009:43). Dalam pengertian lain, dikemukakan bahwa sarana pendidikan adalah "semua perangkat, peralatan, bahan, dan perabot yang secara langsung digunakan dalam suatu kegiatan"(Ibrahim, 2004:2) sedangkan Direktorat Jenderal Pendidikan Dasar dan Menengah dalam Wahyu Sri Ambar memberikan pengertian sarana pendidikan adalah "Sarana diartikan sebagai semua sarana dan prasarana yang menunjang proses belajar mengajar dalam rangka mencapai tujuan pendidikan"Berdasarkan pemaparan di atas maka dapat diambil kesimpulan bahwa sarana pendidikan adalah seluruh peralatan dan perlengkapan yang menunjang penyelenggaraan pendidikan.

Prasarana pendidikan adalah semua perangkat kelengkapan dasar yang secara tidak langsung menunjang pelaksanaan proses pendidikan sekolah (Ibrahim, 2004:2). prasarana pendidikan merupakan semua peralatan dan perlengkapan yang digunakan secara tidak langsung untuk menunjang proses 
pendidikan. Dapat disimpulkan bahwa, sarana dan prasarana pendidikan adalah, peralatan dan perlengkapan yang digunakan untuk menunjang penyelenggaraan proses pendidikan.

\section{Standar Sarana dan Prasarana Bimbingan dan Konseling}

Standar adalah sesuatu yang digunakan sebagai patokan atau batas minimal untuk sesuatu yang diukur(Arikunto, 2009:30). Standar dapat juga diartikan sebagai kriteria yang diperlukan untuk menjadi penentu agar hasil pengukuran berarti(Purwanto, 2009 h.3). Berdasarkan pengertian di atas standar dapat diartikan sebagai ukuran yang digunakan untuk menentukan hasil pengukuran.

Sarana bimbingan dan konseling sebagai peralatan dan perlengkapan yang sangat penting dan dibutuhkan yang menunjang keterlaksanaan program bimbingan dan konseling(Gysbers, 2005:216). Sarana dan prasarana bimbingan dan konseling adalah peralatan dan perlengkapan yang menunjang tercapainya tujuan layanan bimbingan dan konseling(Kemendikbud, 2014:32). Berdasarkan pengertian di atas sarana bimbingan dan konseling merupakan seluruh peralatan dan perlengkapan yang dibutuhkan dalam penyelenggaraan bimbingan dan konseling.

\section{Jenis-Jenis Sarana dan Prasarana Bimbingan dan Konseling}

Pedoman Bimbingan dan Konseling pada Pendidikan Dasar dan Pendidikan Menengah yang mengacu kepada Permendikbud tahun 2014 no.111.Secara garis besar sarana dan prasarana bimbingan dan konseling terbagi menjadi empat bagian yaitu, ruang bimbingan dan konseling, instrumen pengumpul data, kelengkapan penunjang teknis, dokumen program.Ruang bimbingan dan konseling terdiri dari Ruang kerja sekaligus ruang konseling individual, Ruang tamu, Ruang bimbingan dan konseling kelompok, Ruang data.Instrumen pengumpul data terdiri dari instrument pengumpul data tes, intrumen pengumpul data non tes dan alat penyimpan data.

Kelengkapan penunjang teknis terdiri dari Alat tulis menulis, blanko surat,kartu konsultasi, kartu kasus, blanko konferensi kasus, agenda surat, buku-bu- ku panduan, buku informasi tentang studi lanjutan, modul bimbingan, laporan kegiatan pelayanan, data kehadiran peserta didik, leger bimbingan dan konseling, buku realisasi kegiatan bimbingan dan konseling, bahan-bahan informasi pengembangan keterampilan hidup, perangkat elektronik (OHP, LCD), format pelaksanaan pelayanan, dan format evaluasi. Dokumen terdiri dari buku program tahunan, buku program semesteran, dan buku program harian.

\section{Metode Penelitian}

Tujuan penelitian ini adalah untuk mendapatkan gambaran mengenai pemenuhan standar sarana dan prasarana bimbingan dan konseling di Sekolah Menengah Negeri Jakarta Barat. Penelitian ini dilakukan di Sekolah Menengah Negeri di Jakarta Barat.Penelitian dilakukan pada bulan Februari Desember 2014 tahun ajaran 2014-2015.Penelitian ini menggunakan pendekatan kuantitatif dengan metode penelitian deskriptif dengan jenis survei.

Pada penelitian ini populasi penelitian adalah seluruh sekolah menengah negeri di Jakarta Barat. Terdapat 17 SMA Negeri di Jakarta Barat Teknik sampling yang digunakan yaitu sampling Jenuh. Sampel yang akan digunakan dalam penelitian ini sebanyak populasi yang ada yaitu seluruh Sekolah Menengah Atas Negeri di Jakarta Barat. Di dalam proses penelitian ini, sampel menjadi 14 sekolah dikarenakan 3 sekolah SMA N di Jakarta Barat sedang mengalami renovasi bangunan

Teknik pengumpulan data yang akan dilakukan dalam penelitian ini adalah melalui observasi nonpartisipan dengan jenis terstruktur. Uji validitas di lakukan dengan cara uji ahli sedangkan uji realibilitas dilakukan menggunakan teknik interrater realibility dengan hasil 0,8(istimewa). Analisis data menggunakan statistik deskriptif dengan teknik persentase.

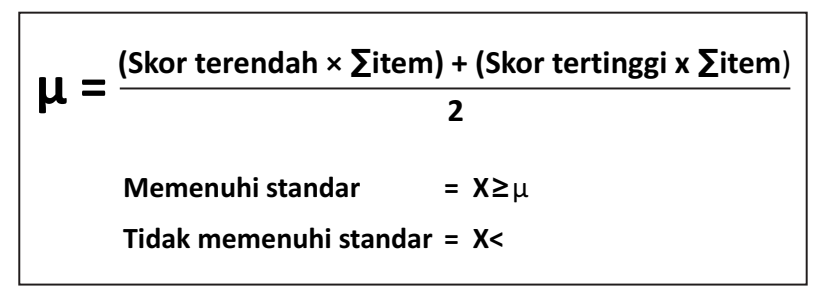




\section{Hasil dan Pembahasan Hasil Penelitian}

Berdasarkan penelitian yang dilakukan terhadap pemenuhan standar fasilitas bimbingan dan konseling di sekolah menengah atas, terdapat satu sekolah memenuhi standar sarana dan prasarana bimbing-an dan konseling dan tiga belas sekolah tidak memenuhi standar sarana dan prasarana bimbingan dan konseling.

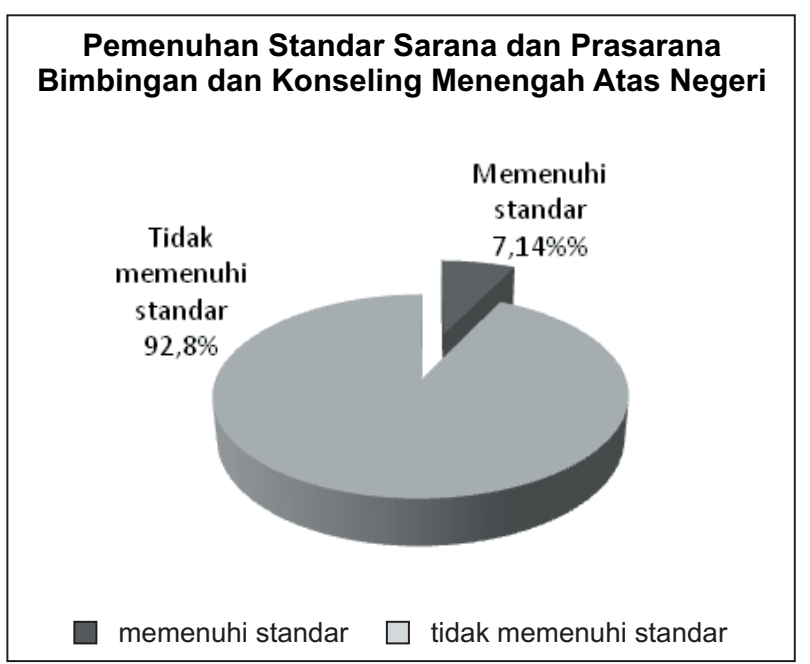

Grafik1.1. Persentase Pemenuhan Standar Sarana dan Prasarana Bimbingan dan Konseling Sekolah Menengah Atas Negeri

Tabel 1.1

Pemenuhan Standar Sarana dan Prasarana Per Aspek

\begin{tabular}{|c|l|c|c|}
\hline No & \multicolumn{1}{|c|}{ Aspek } & $\begin{array}{c}\text { Memenuhi } \\
\text { Standar }\end{array}$ & $\begin{array}{c}\text { Tidak Memenuhi } \\
\text { Standar }\end{array}$ \\
\hline 1 & Ruang bimbingan dan konseling & 0 & 14 \\
\hline 2 & Instrumen pengumpul data & 11 & 3 \\
\hline 3 & Kelengkapan Penunjang Teknis & 10 & 4 \\
\hline 4 & Dokumen & 14 & 0 \\
\hline
\end{tabular}

\section{Pembahasan}

Berdasarkan hasil penelitian yang dilakukan, secara keseluruhan dapat diketahui bahwa dari empat belas sekolah, hanya satu sekolah yang memenuhi standar sarana dan prasarana bimbingan dan konseling.Penyelenggaraan layanan bimbingan dan konseling menemui banyak hambatan yang sangat mengganggu dikarenakan keterbatasan sarana dan prasarana.Salah satu faktor yang menjadi penyebab minimnya sarana dan prasarana bimbingan dan kon- seling adalah dukungan yang kurang kuat dari sekolah, dalam hal ini kepala sekolah. Hasil wawancara selama proses penelitian ini berlangsung, di beberapa sekolah, guru bimbingan dan konseling mengalami kesulitan untuk mendapatkan sarana dan pra sarana yang dibutuhkan. Hal ini dikarenakan kepala sekolah yang kurang tanggap terhadap sarana dan prasarana bimbingan dan konseling. Berdasarkan survei yang dilakukan di sekolah provinsi Nova scotia, kepala sekolah yang menghadiri pelatihanpelatihan di lembaga mengenai program bimbingan dan konseling komprehensif, memiliki peluang untuk keberhasilan pelaksanaan yang tinggi (Sumarah dan Lehr 2002:16).

Pengambilan keputusan kepala sekolah mempengaruhi produktivitas sekolah, baik produktivitas fisik maupun nilai(Kuswardani, 2011:1). Semakin baik pengambilan keputusan kepala sekolah maka semakin baik pula produktivitas dari sekolah tersebut. Kepala sekolah sesuai fungsinya sebagai supervisor sekolah memiliki beberapa tugas, salah satunya berusaha melengkapi alat-alat perlengkapan sekolah termasuk media instruksional yang diperlukan bagi kelancaran dan keberhasilan pembelajaran (Purwanto, 2004:118). Berdasarkan pemaparan di atas, dapat disimpulkan bahwa kepala sekolah memiliki peran yang sangat penting dalam hal ketercapaian standar sarana dan prasarana pendidikan yang ada di sekolah, termasuk di dalamnya sarana dan prasarana bimbingan dan konseling. Kepala sekolah yang memahami pentingnya bimbingan dan konseling akan berusaha memenuhi sarana dan prasarana bimbingan dan konseling sebaik mungkin. Sepuluh kepala sekolah dari sekolah yang tidak memenuhi standar sarana dan prasarana bimbingan dan konseling memiliki latar belakang pendidikan non bimbingan dan konseling.

Masalah yang ditimbulkan akibat sarana dan prasarana yang tidak memenuhi standar sangat banyak.Seluruh sekolah sudah memiliki ruang kerja pembimbing yang memenuhi standar.Namun terdapat sekolah yang masih belum memenuhi kriteria penting yaitu ruang konseling yang tidak kedap suara. Hal ini sangat mengganggu, karena proses konseling menjadi tidak terjamin kerahasiaannya. Ba-nyak keluhan siswa yang tidak nyaman untuk melakukan proses konseling. Guru pembimbing 
pun harus mengeluarkan upaya lebih untuk membuat konseli merasa nyaman. Masalah ini tidak boleh di abaikan. Fasilitas fisik sangat penting karena seringkali menentukan kesan pertama dan kesan permanen dari penyelenggaraan bimbingan dan konseling(Gysbers dan Henderson, 2006:216) . Ruang konseling yang tidak nyaman akan membuat konseli enggan untuk datang kembali.

Dua belas sekolah di SMA N Jakarta Barat memiliki ruang tamu yang memenuhi standar dan dua sekolah lainnya tidak.Ruang bimbingan dan konseling yang tidak memiliki ruang tamu memunculkan masalah baru dalam pelaksanaan layanan bimbingan dan konseling.Seringkali kegiatan yang sedang berlangsung di dalam ruangan bimbingan dan konseling dihentikan ketika kedatangan tamu.Hal ini sangat menganggu karena kegiatan menjadi tertunda atau bahkan tidak terlaksana.

Ruang bimbingan kelompok hanya dimiliki oleh empat sekolah.layanan bimbingan dan konseling kelompok dilaksanakan dengan intensitas yang rendah atau bahkan tidak terlaksana sama sekali di sekolah yang tidak memiliki ruang bimbingan dan konseling kelompok.

Ruang data dimiliki oleh tiga sekolah.Berdasarkan hasil pengamatan, sekolah yang memiliki ruang data, memiliki arsip data yang tersusun rapih sehingga guru pembimbing mudah menemukan data yang dicari ketika dibutuhkan.Sekolah yang tidak memiliki ruang data, instrumen maupun kelengkapan administrasi yang dimiliki guru bimbingan dan konseling berada di banyak tempat sehingga sulit ditemukan ketika dibutuhkan.Data yang ada menyebar di masing-masing loker guru pembimbing, sehingga belum tentu guru pembimbing A, memiliki data yang dimiliki guru pembimbing $\mathrm{B}$, yang seharusnya data itu dimiliki oleh semua guru bimbingan dan konseling.Ruang konseling pustaka tidak dimiliki oleh seluruh sekolah di SMA negeri Jakarta Barat. Buku-buku panduan karir serta buku buku lain yang dibutuhkan peserta didik terletak di sembarang tempat, sehingga tidak dapat dimaksimalkan kegunaannya. Peserta didik harus menunggu guru bimbingan dan konseling mencari dimana buku yang mereka butuhkan, baru setelah itu mereka bisa mengakses informasi yang mereka butuhkan.

Sebelas sekolah memiliki aspek instrumen peng- umpul data yang memenuhi standar, dan tiga sekolah tidak memenuhi standar. Instrumen pengumpul data tes yang digunakan di sekolah adalah tes prestasi belajar (100\%) dan yang paling sedikit digunakan adalah tes kepribadian (28,6\%). Instrumen pengumpul data non tes yang paling banyak diguna-kan adalah Daftar Cek masalah, (92,8\%), sedang-kan yang paling jarang digunakan yaitu skala penilaian $(14,3 \%)$. Alat penyimpan data dimiliki oleh seluruh sekolah dalam bentuk soft document (file), sedangkan dalam bentuk hard document, 13 sekolah memiliki kartu/buku/map peserta didik dan satu sekolah lainnya tidak..

Pada aspek kelengkapan penunjang teknis, terdapat enam sekolah yang tidak memenuhi standar.guru bimbingan dan konseling di sekolah tersebut mengatakan bahwa mereka banyak menemui hambatan ketika ingin melakukan kegiatan bimbingan dan konseling karena ketidaklengkapan kelengkapan penunjang teknis. Sebagian besar bahan-bahan informasi bidang pribadi, belajar, sosial dan karir yang tersedia digunakan berulang-ulang dari tahun ke tahun.Bahanbahan yang digunakan jarang sekali diperbaharui.Hal ini menjadi masalah karena belum tentu bahan yang tersedia mampu memenuhi kebutuhan peserta didik. Namun ternyata, masalah ini terjadi bukan hanya di SMA N Jakarta Barat saja. Dalam skala yang le-bih besar, sumber sumber informasi yang tersedia di CIOLA Directory 1999 di Inggris, (Direktori ini dimaksudkan untuk menjadi sumber informasi bimbingan karir) juga menyediakan informasi yang sudah tidak relevan dalam hal waktu(Jonathan, 1999:6). Inggris sudah mengalami dan membahas masalah ini pada tahun 1999 dan ternyata masalah ini masih menjadi masalah yang sering dijumpai di Indonesia pada tahun 2014. Ketidaktersediaan kelengkapan penunjang teknis yang lain juga menjadi masalah bagi penyelenggaraan layanan bimbingan dan konseling. Sekolah yang tidak memiliki papan pengumuman, kesulitan mengumumkan informasi seperti poster dan sebagainya kepada peserta didik. Kelengkapan yang paling sedikit dimiliki yatu kotak masalah(7,1\%) sedangkan yang paling banyak dimiliki oleh setiap sekolah adalah kartu konsultasi $(100 \%)$.

Pada aspek dokumen seluruh sekolah memiliki buku program tahunan, semesteran dan harian. Pro- 
gram tahunan dan semesteran yang digunakan di tahun ini merupakan pengulangan dari program tahun sebelumnya.Hanya tiga sekolah yang selalu memperbaharui programnya, baik dari segi kebutuhan peserta didik maupun materi yang diberikan. Berdasarkan survei pada 888 konselor sekolah di 514 sekolah menengah atas Wisconsin, 57\% konselor sekolah mengindikasikan bahwa mereka tidak memiliki kalender tahunan jadwal kegiatan yang dilakukan(Burkard, 2012:140). Kondisi ini mencerminkan bahwa konselor sekolah belum memperhatikan perencanaan program dalam penyelenggaraan layanan bimbingan dan konseling.

SMA 78 merupakan satu-satunya sekolah yang memiliki sarana dan pra sarana yang memenuhi standar.Sekolah ini mendapatkan peringkat satu di Jakarta Barat. Guru bimbingan dan konseling di sekolah ini mengatakan bahwa pendidikan yang ditekankan di sekolah ini bukan hanya secara akademik, sekolah juga mendorong peserta didiknya dalam hal non akademik. Sarana dan pra sarana yang menunjang kegiatan pendidikan, termasuk sarana dan pra sarana bimbingan dan konseling sangat diperhatikan. Peserta didik pun terbiasa melakukan konsultasi dan konseling dengan guru bimbingan dan konseling. Penyelenggaraan kegiatan bimbingan dan konseling dilakukan se-suai program tanpa menemui masalah yang berarti. Sarana pendidikan merupakan salah satu faktor eksternal pencapaian prestasi di sekolah (Haryati, 2013:1). Sarana dan prasarana yang memenuhi standar merupakan salah satu faktor yang membuat peserta didik di SMA 78 mampu meraih berbagai macam prestasi.Sarana dan prasarana bimbingan dan konseling yang memenuhi standar juga merupakan faktor penting keberhasilan layanan bimbingan dan konseling di SMA 78.Sementara itu, Jenis layanan bimbingan dan konseling yang dilakukan di tiga sekolah yang sedang direnovasi yaitu layanan bimbingan klasikal. Hanya layanan itu yang dapat dilakukan, karena guru bimbingan dan konseling tidak mendapatkan prasarana sementara yang dapat digunakan untuk layanan bimbingan dan konseling. Kondisi ini menimbulkan kerugian besar, karena banyak peserta didik yang akhirnya tidak bisa melakukan konsultasi ataupun konseling.

\section{Daftar Pustaka}

Arikunto, Suharsimi. (2010). Prosedur Penelitian Suatu Pendekatan Praktik.Jakarta:Rineka cipta

Arikunto, Suharsimi.(2009). Evaluasi Program Pendidikan. Jakarta:Bumi Aksara

Arum, Wahyu Sri Ambar.(2007). Manejemen sarana dan Prasarana Pendidikan. Jakarta: Multi Karya Mulia

Bhafadal, Ibrahim. (2004). Manajemen Perlengkapan Sekolah:Teori dan Aplikasinya. Jakarta:Bumi Aksara

Borders, Dianne dan Sandra M Drury.(1992). Counseling Programs A Guide to Evaluation. California:Corwin Press.

Brown, Jonathan. (1999). Does Guidance Have a Future? Towards a Distinctive Position. Cambridge: Taylor\&Francis Ltd

Burkard, Alan. (2012). Implementation Challenges and Training Needs for Comprehensive School Counseling Programs in Wisconsin High School. America: Asca.

Departemen Pendidikan Nasional.(2008). Penataan Pendidikan Profesional Konselor dan Layanan Bimbingan dan Konseling dalam Jalur Pendidikan Formal.

Gysbers, Norman dan Patricia Henderson.(2005). Developing \&Managing Your School Guidance and Counseling.Alexandria:American Counseling Association.

Haryati.(2013). Peran Manajemen Sarana Pendidikan dalam Pencapaian Prestasi Siswa.

Iska, Zekri Neni. (2012). Pengantar Bimbingan dan Konseling. Jakarta:Kizi brother's.

Kemendikbud.(2014). Pedoman Bimbingan dan Konseling pada Pendidikan Dasar dan Pendidikan Menengah.

Kuswardani, Ika. (2012). Hubungan Antara Pengambilan Keputusan Kepala Sekolah dengan Produktivitas Sekolah.

Mulyasa.(2003). Manajemen Berbasis Sekolah. Bandung:Remaja Rosda Karya

Nurihsan, Ahmad Juntika. (2005). Layanan Bimbingan dan Konseling. Bandung:PT Refika Aditama

Prayitno dan Erman Amti.(2004). Dasar-Dasar Bimbingan dan Konseling. Jakarta:PT Rineka Cipta.

Purwanto.(2004). Administrasi dan Supervisi Pendidikan. Bandung:Remaja Rosda

Purwanto.(2009). Evaluasi hasil Belajar. Yogyakarta: Pustaka Pelajar.

Stiyowati, Sulis. (2013). Hubungan antara persepsi siswa terhadap pribadi konselor dan fasilitas BK dengan minat siswa untuk memanfaatkan layanan konseling di sekolah". Jurnal BK UNESA .Vol.03 No.01.

Sukardi, Dewa Ketut. (2008). Pengantar Pelaksanaan Program Bimbingan dan Konseling di Sekolah. Jakarta:PT Rineka cipta. 
John Sumarah dan Ron Lehr.(2002). Catching The Vision: Guidance and Counseling In Nova Scotia's School. Canada:Canadian Counseling and Psychotheraphy Association

Suprapto.(2013). Metodologi Penelitian Ilmu Pendidikan dan Ilmu-Ilmu Pengetahuan Sosial. Yogyakarta:Center for academic publishing service.

Yusuf, Syamsu dan Juntika Nurihsan.(2010). Landasan Bimbingan dan Konseling. Bandung:Rosdakarya. 